\title{
Examining Japanese Planning System through the National Territory and Housing Policies: A Focus on Changing Characteristics and Implications
}

\author{
Sam-Su Lee ${ }^{1}$ and Jae-Su Lee
}

(Received March 5, 2011 / Revised July 4, 2011 / Accepted July 18, 2011)

\begin{abstract}
There are similarities between Korea and Japan in terms of national planning and development system and housing policies. Japan has suffered from great shifts of social and economic systems due to skyrocketing land prices for three times and the collapse of the bubble economy after the Second World War. The study reviews historically important changes in the national territory and housing policies for last 60 years in Japan. It also investigates changing trends and characteristics of many socioeconomic indicators with regard to population, housing and other fields in response to these policies. First of all, Japan has experienced significant economic growth before and after the 1960's, and the era of national rebuilding projects in the 1970's. After then, the period of the bubble economy has emerged since 1980; however, it suffered from skyrocketing land values between the late 1980's and the early 1990's, and the collapse of Japanese bubble economy in the early 1990's. In response, many urban regeneration policies and projects were proposed to recover the national economy since 2000. It is found that these national territory development and housing supply policies throughout the country have been influenced by the changing characteristics of social and economic conditions. Since the housing supply ratio in 1968 reached up to around $100 \%$ on average, Japan has been focusing attention to improving the residential and living quality for existing housing stock rather than supplying new housing units through large-scale new town projects. These experiences are full of helpful suggestions for our future housing and urban regeneration policies as we reach to more than $100 \%$ of housing supply ratio on average.
\end{abstract}

Key words National Territory Planning, Housing Policy, Urban Regeneration, Japan

\section{Introduction}

\subsection{Backgrounds and objectives}

The planning idea of growth and development in the last century has changed to the concept of maturity and management because the public have been more and more interested in urban and residential environments in this century. According to the paradigm shift, future land and housing policies need to be reshaped as new approaches to urban regeneration projects become more supported than large-scale development and redevelopment projects.

Along with the stream, a governmental plan titled "A Plan for Revitalizing Housing Supply in Downtown and Supplying Affordable Housing (Bogeumjari)" in September 2008, emphasized that continuous housing supply was essential to tackle the increasing demand for residential places in downtown areas. It presented that 60 percent of new residential units would be provided in urban areas while focusing on conventional redevelopment and reconstruction and reinforcing the role of private market system. We can also realize that the public policy has been changing from large-scale land and new town development projects to urban regeneration programs including downtown redevelopment, reconstruction and transit-oriented development.

According to the interim result of the 2010 Census, the national population growth rate is slowing down; however, the number of people living in the Seoul Metropolitan Region amount to about 50 percent of the national population. In addition, average members per household decreases steadily, while both one-person households and the ratio of apartment houses to total housing stock increase notably. A number of foreign governments have been trying to address these social and economic trends by legalizing new land and housing strategies. In particular, Japan, having similar land and housing development policies to Korea, has suffered from social and economic changes including skyrocketing land prices and collapse of the bubble economy for three times since the end of the Second World War.

There have been some studies addressing the issues of land and housing policies in Japan; Kim and Kim (2008) proposed some policy implications for Korea after examining housing supply

1) Research Fellow, Land \& Housing Institute (Main author: leesamsu@hotmail.com)

2) Associate Research Fellow, Department of Urban Planning Research, Seoul Development Institute (Corresponding author: leejs@sdi.re.kr) 
policies and housing market system in Japan. Yoo (2006) paid attention to Japanese land development system and some related issues in order to ease the lack of housing stock in Japan. Lee et al. (2008) investigated systematic changes of public corporations along with changing laws and strategies with regard to national development and housing supply. In addition, Lee et al. (2010) inquired into Japanese legal system and achievements related to large-scale land development to improve Land Development Promotion Law in Korea.

The majority of the studies have mainly focused on national land and housing development policies in a specific point of time rather than their changing characteristics by times in Japan since the Second World War. This article, therefore, investigates the changing trends and traits of Japanese land and housing system and strategies along with the changes of social and economic conditions during the last 60 years in Japan. It makes an analysis of the changing attributes in social and economic system and measures such as population and housing stock by times which are expected to cause these policy and systematic shifts. This research also intends to propose policy implications for land development and housing supply plans and strategies resulted by ongoing changes in our social and economic system.

\subsection{Scope and methodology}

For the purpose of suggesting policy implications from the changes of land and housing policies, this study examined their changing characteristics as the results of changing social and economic conditions in Japan. By conducting comparative analyses of social and economic conditions and changes both in Korean and Japan, future outlook and policy suggestions are presented for establishing more sensible and plausible land and housing policies in Korea.

The research was conducted as follows. First, relevant literature is reviewed to understand the changes of land and housing policies in Japan. Then, their changing attributes and the relationships with social and economic indicators are investigated by analyzing statistical data including interim data of 2010 census, the number of new housing supply and housing stocks, housing and land survey.

\section{Changes of land and housing policies by periods in Japan}

Since the end of the Second Word War, Japan has experienced massive changes in land and housing policies amongst the changes of social and economic environments such as repeatedly soaring land prices and collapses of the bubble economy for three times. The first event happened during the rapid growth period around 1960, the second was Japanese rebuilding boom 1 ) in the

1) The National Rebuilding Plan was proposed to address extenalities from dense population and pollutions, and to promote local industries early 1970's, and the last was divided into three events representing social and economic changes: skyrocketing land price during the bubble economy between the late 1980's and the early 1990's; the collapse of the bubble economy during the early 1990's; and urban regeneration policies for vitalizing national economy since the 2000's.

\subsection{0's: growing rapidly and establishing housing supply plans}

During the 1950's, the central government has established first ten-year housing supply plan to solve the shortage of housing stock. Also, several authorities such as Housing Corporation were established to promote public housing supply. The National Territory Comprehensive Development Act was enacted in 1950 so that integrated approaches and initiatives were presented in consideration of social, economic and cultural conditions.

Before and after 1960's, the first phase of soaring land prices took place, as industrial land prices skyrocketed primarily due to rapid development of increasing private investments into manufacturing and facilities alongside high economic growth rate. Indeed, the scarcity of housing supply in three major cities2) become serious because of significant population influx, and rapid urban sprawl.

After the Ministry of Home Affairs (MOHA) was established in 1960, various policies and systems upon land, urban and community development such as National Territory Construction Plan, Metropolitan Development Plan, Promotion Act for Developing Northern Inland Region, and Promotion Act for Developing Chugoku Region were presented and implemented. The first apartment or mansion ${ }^{3)}$ construction boom occurred in 1964. The Housing Construction Plan Act was legislated so that comprehensive housing plan could be set forth by central government, and cooperation between central and local governments were encouraged. Based on the efforts, Tama New Town Development Project as the First Five-year Plan for Housing Construction was implemented. Some new polices were newly legalized in 1968: line setting system to divide urban area into urbanization promotion areas and urbanization control areas, zoning system, development permission system, and New City Planning Act ${ }^{4}$ enabling to establish the City Planning Commission. It was during the period that first achieve the goal of one house per household when the national average of houses per household scored 1.01. The second phase of the apartment construction boom took place at this time.

and manufactures by connecting major urban areas with highway networks and shinkansen.

2) They are Tokyo, Osaka, and Nagoya metropolitan areas.

3) An apartment is a high-rise residential building that is similar to the structure in Korea.

4) Japan has had Urban Planning Act since 1919. As the current law was enacted in 1968, it is called New City Planning Act. 


\subsection{0's: rebuilding boom and developing new towns}

Following to the enactment of the Tsukuba Science City Construction Act in 1970, new town development projects began to be enforced. In 1971, the Second Five-year Plan for Housing Construction has been established in which the goals of one-room-per-person and 9.5 million new homes were pursued.

'New Urban Infrastructure Act' was legalized in 1972 in order to develop regional growth poles in the areas distant from downtown. New trends have appeared such as cash flow problems, rebuilding the Japanese Archipelago, population centralization in large cities, corporations' land acquisitions, second period of soaring land price caused by speculative needs, and the third apartment construction boom. The Act on the Utilization of the National Territory was enacted in 1974 for setting up national land use plans and managing land transactions. Many mansions or apartments started to be constructed in suburban areas, and the Kohoku New Town Project in Yokohama was set forth. 846 real estate companies, on the other hand, had been bankrupted consecutively.

Land readjustment promotion district, apartment complex district, and housing and neighborhood maintenance district were designated in 1975, and the Act on Special Measures Concerning the Promotion of Housing and Residential Land Supply in Major Urban Areas was set to help launch the land readjustment projects in specially designated districts and residential housing readjustment projects. Additionally, the Land Development Corporation established in that year had authority to endorse other corporations to implement land readjustment projects or other similar projects. It could also provide public facilities, local railways and water works. For the first time, average growth rate of the official land price scored minus due to the global oil shock.

The Third Five-year Plan for Housing Construction focusing on improving housing quality was established in 1976 under the plan of supplying 8.6 million houses to achieve the goal of basic and average standards of residential quality. One year after, the Third Comprehensive Plan for National Territory Development containing the residential right for local residents was effective, and the fourth apartment construction boom took place. In the late 1970's, mini new towns increased more than large new cities.

\subsection{0's and early 1990's: bubble economy and its collapse}

In 1981, the first Machizukuri Ordinance in Kobe, and The Forth Five-year Plan for Housing Construction aiming to build 7.7 million new houses were established. Japanese Housing Corporation and the Urban Development Corporation were merged to be the Housing and Land Development Corporation authorized to execute special redevelopment projects.

The Rebuilding Plan of the Capital City was created in 1985 to overcome mono-centric spatial structure in Tokyo metropolitan area by constructing multi-centric spatial network. The Forth General Plan for Readjusting Capital Region and the Fifth
Five-year Plan for Housing Construction were prepared to supply 6.7 million new houses. Land trust system was also introduced for the nation-owned land in 1986. The plan intended to enhance the quality of residential environment by setting up related standards. In 1987, the Forth Comprehensive Plan for National Territory Development was presented mainly to design multi-centric dispersed spatial structure and transportation network. Also, the Special Act for Promoting Urban Development by Private Sector was enacted and designated private urban development promotion zones in order to encourage development projects in urban areas by decent private construction companies. At the same time, the third period of soaring land price took place because of three forces: demands for business areas in downtown Tokyo, increasing needs for surrounding residential development, and more speculative demands for available land. To address them, the Act for Promoting Multi-centric Dispersed National Territory and the Basic Act for Land was approved in 1988 and 1989, respectively. To get over the situation of bubbling economy, particularly in 1990's, some policies and measures were initiated including land value tax in 1992, fixed property tax rates and increasing succession tax, increased special land value tax and so on.

The Sixth Five-year Plan for Housing Construction were proposed to provide 7.3 million new houses and to achieve the goal of $95 \mathrm{~m}^{2}$ per house. As land price was going down continuously, the Ministry of Construction suggested new vision for real estate industry in 1992. In 19935), the Summary of Constructing Environment-friendly Model City was promulgated for informing and educating the public to minimize environmental burdens so that environment-friendly housing and town projects were to be conducted furthermore. The Seventh Five-year Plan for Housing Construction was prepared in 1996 suggesting that more than half of total national households should take minimum residential standards, and a household should occupy $100 \mathrm{~m}^{2}$ in average, and 7.3 million new houses should be provided.

As an effort of coordinated and collaborated policies and measures to vitalize inactive downtowns and commercial activities in the areas, and to readjust central streets and blocks in urban areas, the Act on Comprehensive Measures for Readjusting Streets and Vitalizing Commercial and Business Activities in Downtowns6) was enacted in 1998. In addition, the Housing and

5) New vision for real estate industry proposed some future directions for real estate companies including improving real estate management, creating and maintaining urban environment, enhancing social credit and unity and organizing cooperative actions to globalization of its market.

6) The existing law lacked in enhancing the public good and various urban activities such as businesses and commercial activities to increase residential population who were the source of vitalizing streets of town. The plan to lead vitalizing downtowns was mandated by the central government, but it was realized that the system had limitations because it had no means to ensure positive actions by local residents. It was hence redesigned as 
Urban Readjustment Corporation' became the Urban Infrastructure Readjustment Corporation with the changes of its organization and functions.

\subsection{Late 1990's and 2000's; Administrative Reform and Urban Renaissance}

The collapse of the bubble economy in the early 1990's made land prices down in the first decade of 2000's. To deal with the issue, a plan for administrative reform had been designed by 2005 when the cabinet's resolution was decided in December 2004.

The government established the Headquarter of Administrative Reform by appointing the Prime Minister as its head so as to make the reform more comprehensive and positive. The missions of the Minister of Administrative Reform were presented in three categories: reforming special corporations, public service system, and public service corporations.

When the period of urban regeneration has begun since 2000, the Urban Renaissance Headquarter was officially formed ${ }^{7)}$ to enforce urban renewal policies and measures by cabinet's resolution on May 8th, after the Koizumi administration's inauguration on April 8th of the year. Major urban regeneration projects were conducted after the Act on Special Measures Concerning Urban Renaissance was enacted in April 2002 as a result of the administration's efforts. In 2001, the Eighth Five-year Plan for Housing Construction, setting up the targets of supplying 6.4 million decent new houses and readjusting residential buildings for meeting the demand.

There was concerns about the imbalance between the demand and the supply in 20038) because office buildings greatly increased due to consistent constructions in downtowns of big cities such as Tokyo in the early 2000's, but its demand did not come up with their supply due to long-term economic recession. In 2004, a special incorporation, the Urban Regeneration Corporation was organized as an independent administrative organization. It was

a whole in 2006 by enacting the Act on Comprehensive Measures for Readjusting Streets and Vitalizing Commercial and Business Activities.

7) Urban Renaissance Headquarter was launched only two weeks after the administration's inauguration because its formation was decided at the ministerial meeting on economic emergency held on April 6th 2001. The renewal policy was mandated as a part of Koizumi administration's reform policies. The headquarter was organized with the goals of urban regeneration for new planning paradigm including comprehensive perspectives from the environment, disaster prevention and globalization. Its policies aimed for efficient land use and new concept of urban regeneration for the $21^{\text {st }}$ century.

8) In spite of unclear expectation that the demands for new office buildings would be increased, new buildings were consistently located in downtowns. As a consequence, not only new buildings but also existing buildings could not be properly occupied by tenants. This also happened in suburban areas, resulting in an increasing number of vacant office buildings by times nationally. aimed to be a producer of urban renaissance projects based on the accumulative knowledge and experiences of the Urban Infrastructure Readjustment Corporation (Lee, 2008).

In the mid 2000's, some laws and systems related to land and housing development polices such as the National Territory Comprehensive Development Act and the Housing Development and Planning Act was fundamentally redesigned as with policy changes. The National Spatial Planning Act was newly enacted in 2005 when the National Territory Comprehensive Development Act was revised. The National Spatial Planning Act enabled to prepare both the National Land Use Plan and the National Spatial Strategies. The National Comprehensive Development Plan which had been perviously presented five times was replaced by th National Land Use Plan in accordance with the changing conditions of decreasing population. The Housing Development and Planning Act that had played its role for 40 years since 1966 was abolished and replaced by the Basic Act for Housing. In addition, the Basic Plan for Housing took the place of the Five-year Plan for Housing Construction while mainly concentrating on residential quality, housing stock and housing plans in the $21^{\text {st }}$ century.

\section{Characteristics of national territory and housing policies in Japan}

\subsection{Changes of population and housing stock}

\subsubsection{Population measures}

It was in 1970 that the population of Japan recorded first over 100 million as it was 103.7 million people. But population in Japan, still having as many as 127.66 million people in 2005 , show that increasing pace has consistently been dull since 1980's. On the contrary, households9) have been steadily increased as it recorded 27 million households in 1970, and 49.53 million in 2005, showing that average members per household have been decreased. Also, the number of members per household became less than 4 in 1970, which dropped to 2.58 in 2005 . Total population was expected to increase by 2005 , but it turned to decrease from 2006. As a result, the population will drop until 2050 when it is expected to be 100 million similar to the number in 1968.

Along with decreasing population, Japan first entered to the aging society in 1970 that ratio of the 65 year and over population was $7.1 \%$, and broke $10 \%$ of the ratio in 1985. In 1994, Japan has first entered to the aged society as the ratio was $14.1 \%$, and it entered to the post aged society in 2006. Indeed, it is expected that the ratio of 65 year and over population becomes $35.7 \%$ in 2050 .

The population decline in Japna is different from previous world experiences because it is expected to be a nationwide

9) In Japan, a household does not mean the member living together in the same house but members of a family. 
Table 1. A summary of national territory and housing plans in Japan

\begin{tabular}{|c|c|c|c|c|c|}
\hline Classification & $\begin{array}{c}\text { National Land Development } \\
\text { (National Land Development Act) }\end{array}$ & \multicolumn{3}{|c|}{$\begin{array}{c}\text { National Land Use Plan } \\
\text { (National Land Use Planning Act) }\end{array}$} & $\begin{array}{l}\text { 5-Year Housing Plan } \\
\text { (Act of Housing Plan) }\end{array}$ \\
\hline Purpose & $\begin{array}{c}\text { General and fundamental plans of } \\
\text { central and local governments are } \\
\text { established to deal with the } \\
\text { followings; } \\
\text { Development of land, water, and } \\
\text { other natural resources. Prevention } \\
\text { from disasters of flood and wind. } \\
\text { Adjusting and placing urban and rural } \\
\text { areas. Governmental plan of optional } \\
\text { locations by industries, electricity, } \\
\text { and transportation. }\end{array}$ & \multicolumn{3}{|c|}{$\begin{array}{l}\text { National Land Use Plan designated by } \\
\text { metropolitan and local governments. }\end{array}$} & $\begin{array}{l}\text { Housing construction plan is set for } \\
\text { people to enjoy appropriate level of } \\
\text { residential conditions. }\end{array}$ \\
\hline Period & Not Regular & \multicolumn{3}{|c|}{ Not Regular } & Every 5 year \\
\hline $\begin{array}{l}\text { Planning } \\
\text { Structure }\end{array}$ & $\begin{array}{c}\text { National General Plan } \\
\downarrow \\
\text { Metropolitan General Plan } \\
\downarrow \\
\text { Local General Plan }\end{array}$ & $\begin{array}{l}\text { National } \\
\text { Land } \\
\text { Use } \\
\text { Plan }\end{array}$ & $\begin{array}{c}\text { National Plan } \\
\downarrow \\
\text { Prefectural Plan } \\
\downarrow \\
\text { Municipal Plan }\end{array}$ & $\begin{array}{c}\text { Land Use Master } \\
\text { Plan } \\
\text { (Metropolitan } \\
\text { Areas) }\end{array}$ & $\begin{array}{c}\text { 5-Year Housing Plan } \\
\downarrow \\
\text { 5-Year Housing Plan by Metropolitan } \\
\text { Government } \\
\downarrow \\
\text { 5-Year Housing Plan } \\
\text { by Local Government } \\
\end{array}$ \\
\hline Planning & $\begin{array}{l}\text { 5th National Land Plan established } \\
\qquad \rightarrow \text { Abolished }\end{array}$ & \multicolumn{3}{|c|}{$\begin{array}{l}\text { 4th National Land Use Plan established } \\
\text { (national plan) }\end{array}$} & $\begin{array}{l}\text { 8th Housing Construction Five-year } \\
\text { Program established } \rightarrow \text { Abolished }\end{array}$ \\
\hline $\begin{array}{l}\text { Current Laws } \\
\text { and Plans }\end{array}$ & $\begin{array}{l}\text { - Changed to National Spatial Planning } \\
\text { Act (2005) } \\
\text { - National Spatial Strategies established }\end{array}$ & & - & & $\begin{array}{l}\text { - Changed to Basic Act for Housing } \\
\text { (2006) } \\
\text { - Basic Plan for Housing established }\end{array}$ \\
\hline
\end{tabular}

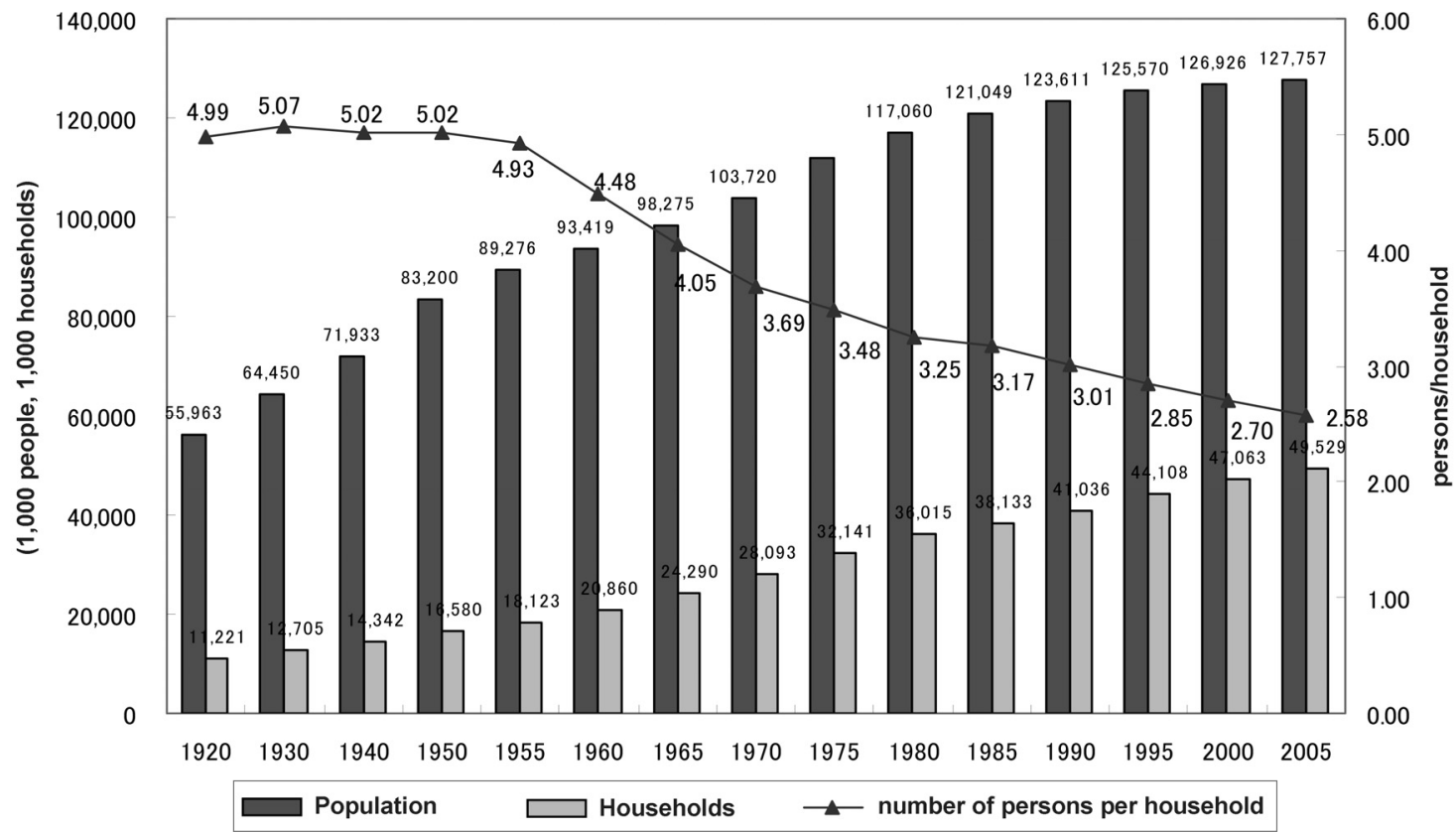

Source : Ministry of Internal Affairs and Communications, Bureau of Statistics, National Census

Fig. 1. The Changes of Population and Households 


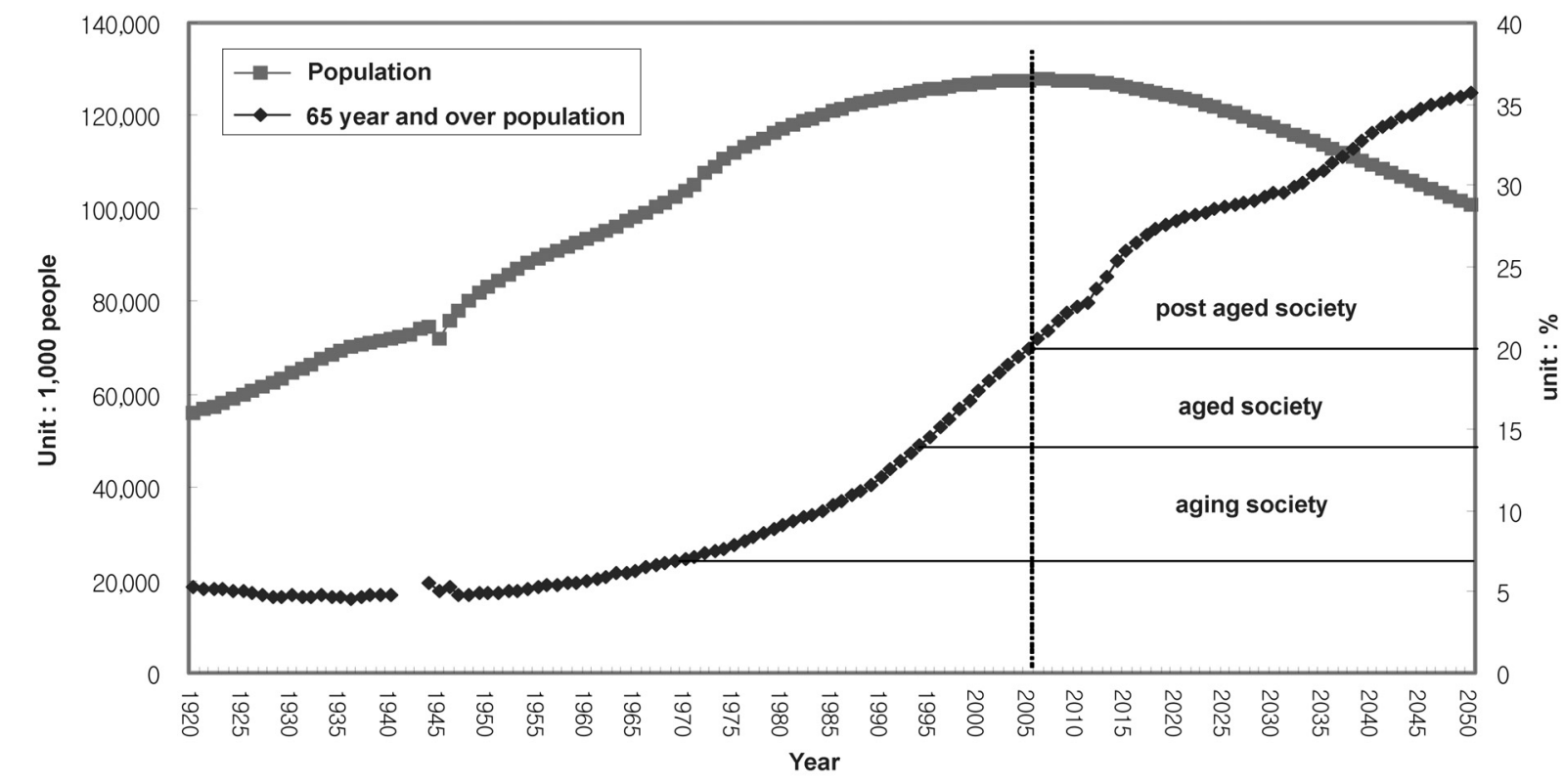

Source : Ministry of Internal Affairs and Communications, Bureau of Statistics

Fig. 2. The estimation of future population and 65 year and over population

decline. the main cause of Japan's population decline is a natural decline owing to a fertility rate that is too low to sustain Japan's population. Not only a regional population decline but also a national population decline has been occurring(Uemura and Uto. 2010).

\subsubsection{Housing stock and construction performance}

Total housing stock in Japan has increased by 3.2 times for 50 years, from 17.4 million in 1958 to 57.6 million in 2008. Taking a look at the number of new houses since 1960, it had rapidly increased until 1970, but there has been no distinctive trend from 1970 to 1996 even though it has repeatedly up and down. For six years since 1996 to 2002, however, the number of newly constructed houses decreased rapidly; it diminished by almost 500,000 during this period. It has shown in Figure 3 that around 1.2 million stocks on average have been maintained since 2000 .

It was in 1968 that was Japan has achieved over $100 \%$ in housing supply ratio ${ }^{10)}$, which became $114.3 \%$ in 2003 as it has steadily increased since 1950 's. Also, the number of houses per 1,000 people has grown from 253 in 1968 to 422 in 2003, amounting to about twice for 30 years.

When the housing supply ration was below $110 \%$, it was observed that new housing construction activities have rapidly declined. However, the number of new houses has been kept between 1,2 million and 1.3 million as the ratio became over $110 \%$ with a varying degree.

10) There has been no concept of the housing supply ratio in Japan since 1980's. Figures in this paper are calculated from the ratio of total houses to total households.
Table 2. Housing units and total households in Japan

\begin{tabular}{c|c|c|c|c}
\hline Classification & Houses & Households & $\begin{array}{c}\text { Housing } \\
\text { supply ratio } \\
(\%)\end{array}$ & $\begin{array}{c}\text { Number of } \\
\text { houses per 1,000 } \\
\text { population }\end{array}$ \\
\hline 1958 & $17,934,000$ & $18,647,000$ & 96.2 & 195 \\
\hline 1963 & $21,090,000$ & $21,821,000$ & 96.7 & 219 \\
\hline 1968 & $25,591,200$ & $25,319,900$ & 101.1 & 253 \\
\hline 1973 & $31,058,900$ & $29,650,900$ & 104.7 & 285 \\
\hline 1978 & $35,450,500$ & $32,834,900$ & 108.0 & 308 \\
\hline 1983 & $38,606,800$ & $35,196,800$ & 109.7 & 323 \\
\hline 1988 & $42,007,300$ & $37,812,200$ & 111.1 & 342 \\
\hline 1993 & $45,878,800$ & $41,159,100$ & 111.5 & 367 \\
\hline 1998 & $50,246,000$ & $44,359,500$ & 113.3 & 397 \\
\hline 2003 & $53,890,900$ & $47,164,900$ & 114.3 & 422 \\
\hline 2008 & $57,593,000$ & $49,989,000$ & 115.2 & 452 \\
\hline & & \multicolumn{3}{|c}{}
\end{tabular}

\subsubsection{Housing types and supply by sectors}

In terms of housing types, the majority of housing type was single-family housing from 1977 to 1984 when only new housing units were considered; however, apartments have been dominant for about ten years after 1985. Since 1995, the amount of both single-family and apartment housing types has become similar.

The private sector has made more contribution to housing supply. The number of new houses funded by the private sector was more than that financially supported by the public sector except for the period between 1982 and 1994 when they were almost same. After 1999, the number of new houses funded by public sector has greatly decreased while the number of private- 


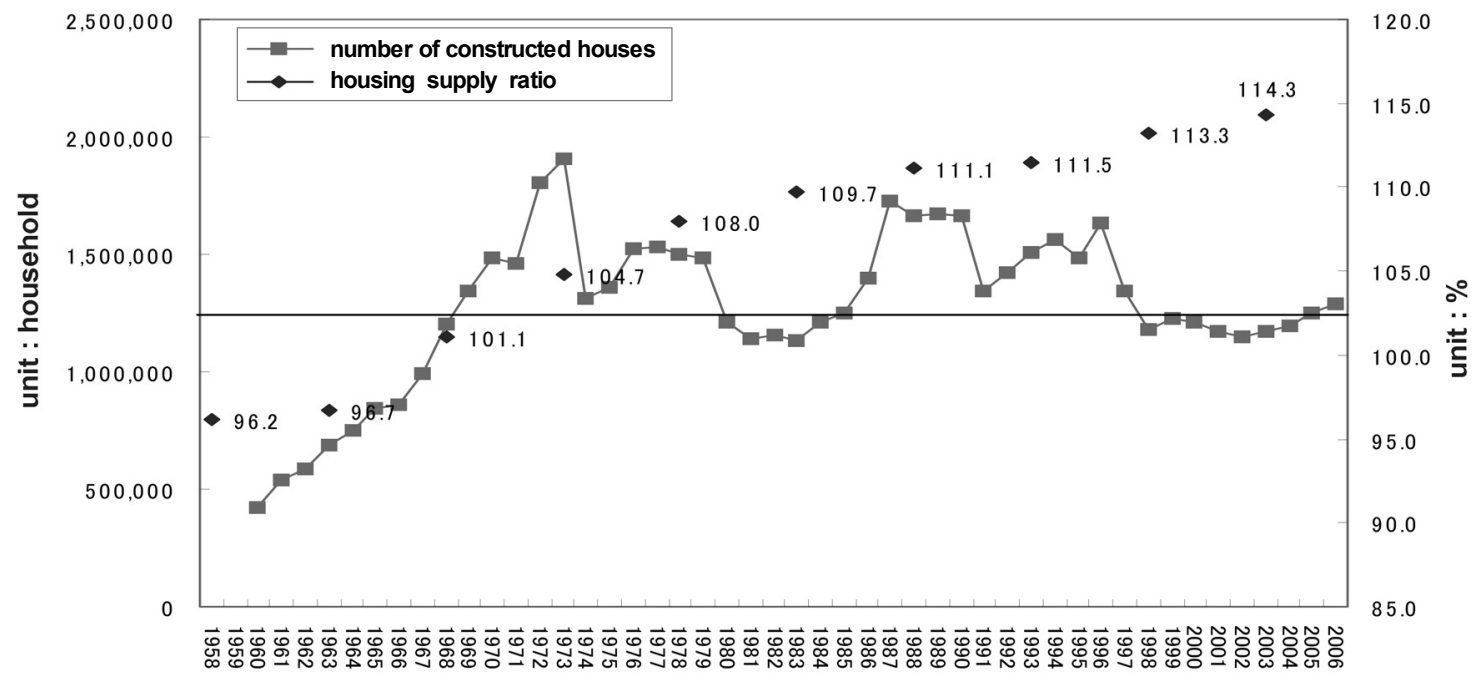

Source : Ministry of Land, Infrastructure, Transport and Tourism, Statistics of Housing by respective years.

Fig. 3. The relationship between housing supply ratio and new housing units

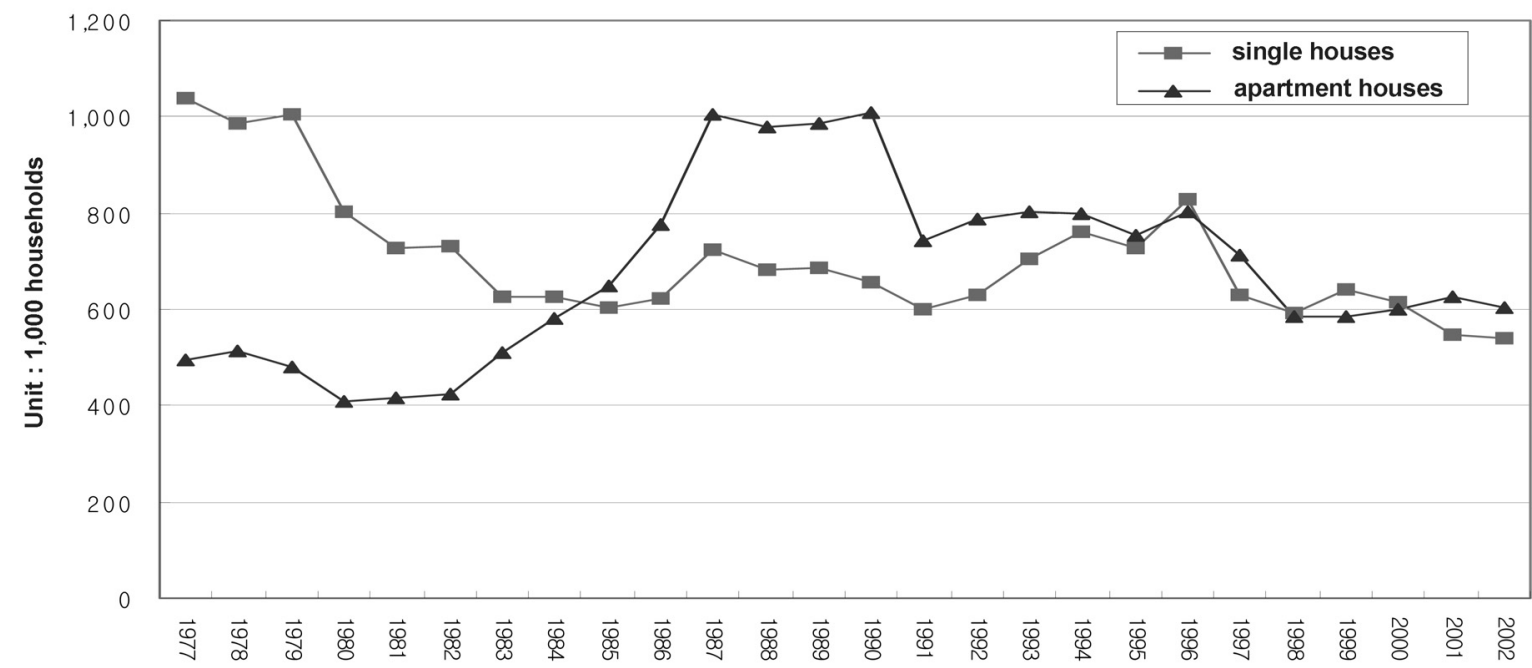

Source : Ministry of Land, Infrastructure, Transport and Tourism, Statistics of Housing by respective years.

Fig. 4. The Number of new housing units by types

funded houses has constantly augmented. In particular, total new housing units have clearly dwindled since the Urban Infrastructure Adjustment Corporation became an independent corporation in 2004.

\subsection{Policy changes related to changing socioeconomic circumstances}

Similar to Korea, Japan has been suffering from the shortage of housing stock for a long time. When one fifth of total housing units or 14 million houses had been destroyed during the World War II, about 4.2 million were in short supply. The problem has been more serious during the 1960's, the economic development period because the population in cities has sharply increased.

Due to the experiences, various efforts have been made to enlarge land and housing supply during 1960's. The National
Land Development Plan were established in 1962 and Housing Construction Five-year Program were initiated in 1966. As a consequence, a goal of one house per one household (100\% of housing supply ratio) was achieved throughout the nation in 1968, and in all metropolitan areas in 1973. In addition, above half of total households reached to minimum residential environment suggested by the central government. ${ }^{11}$ )

It was after 1968 that strived to enhance the quality of existing housing units as the housing supply ratio amounted to above $100 \%$. It was shown that the shortage of housing units has been relieved as the number of houses per unit population increased by

11) Housing supply ratio only measures a quantitative level of total houses compared with total households. It does not imply the quality of residential environment. 
Table 3. An outlook of national development of Japan

\begin{tabular}{|c|c|c|c|c|c|}
\hline Classified & $\begin{array}{c}1^{\text {st }} \text { Comprehensive Plan } \\
(1962-70)\end{array}$ & $\begin{array}{c}2^{\text {nd }} \text { Comprehensive Plan } \\
(1969-85)\end{array}$ & $\begin{array}{c}3^{\text {rd }} \text { Comprehensive Plan } \\
(1977-87)\end{array}$ & $\begin{array}{c}4^{\text {rd }} \text { Comprehensive Plan } \\
(1987-2000)\end{array}$ & $\begin{aligned} 5^{\text {th }} & \text { Comprehensive Plan } \\
& (2000 \sim \text { present })\end{aligned}$ \\
\hline Back & $\begin{array}{c}\text { Industrial development } \\
\text { Gap between city central } \\
\text { and rural area }\end{array}$ & $\begin{array}{c}\text { Population's centralization } \\
\text { to big cities. } \\
\text { Environmental quality } \\
\text { emphasized }\end{array}$ & $\begin{array}{c}\text { Oil shock, } \\
\text { Safe development } \\
\text { emphasized }\end{array}$ & $\begin{array}{c}\text { Centralization to big } \\
\text { cities, change of industrial } \\
\text { structure }\end{array}$ & $\begin{array}{l}\text { Population decreased, } \\
\text { aging, social structure } \\
\text { changed }\end{array}$ \\
\hline Basic goal & $\begin{array}{l}\text { Resolving regional gaps } \\
\text { Establishing infrastructure }\end{array}$ & $\begin{array}{c}\text { Environmental quality } \\
\text { emphasized }\end{array}$ & $\begin{array}{c}\text { Comprehensive adjustment } \\
\text { of human environment } \\
\text { adjustment }\end{array}$ & $\begin{array}{l}\text { multi polar style land } \\
\text { formation }\end{array}$ & $\begin{array}{l}\text { multi polar style land } \\
\text { formation }\end{array}$ \\
\hline Method & $\begin{array}{c}\text { Growth pole based } \\
\text { development } \\
\text { (New industrial city, } \\
\text { Special area for industrial } \\
\text { adjustment etc.) }\end{array}$ & Large scale projects & $\begin{array}{c}\text { Idea of local residential } \\
\text { rights, measuring } \\
\text { excessiveness and scanty }\end{array}$ & $\begin{array}{c}\text { Idea of exchange network, } \\
\text { independent local } \\
\text { development }\end{array}$ & $\begin{array}{l}\text { Valuing each region's } \\
\text { character, regional } \\
\text { requirement based } \\
\text { planning }\end{array}$ \\
\hline
\end{tabular}

Source: Ministry of Land, Infrastructure, Transport and Tourism (http://www.mlit.go.jp)

Table 4. A summary of housing policy on the basis of 5 Year Plan of Housing

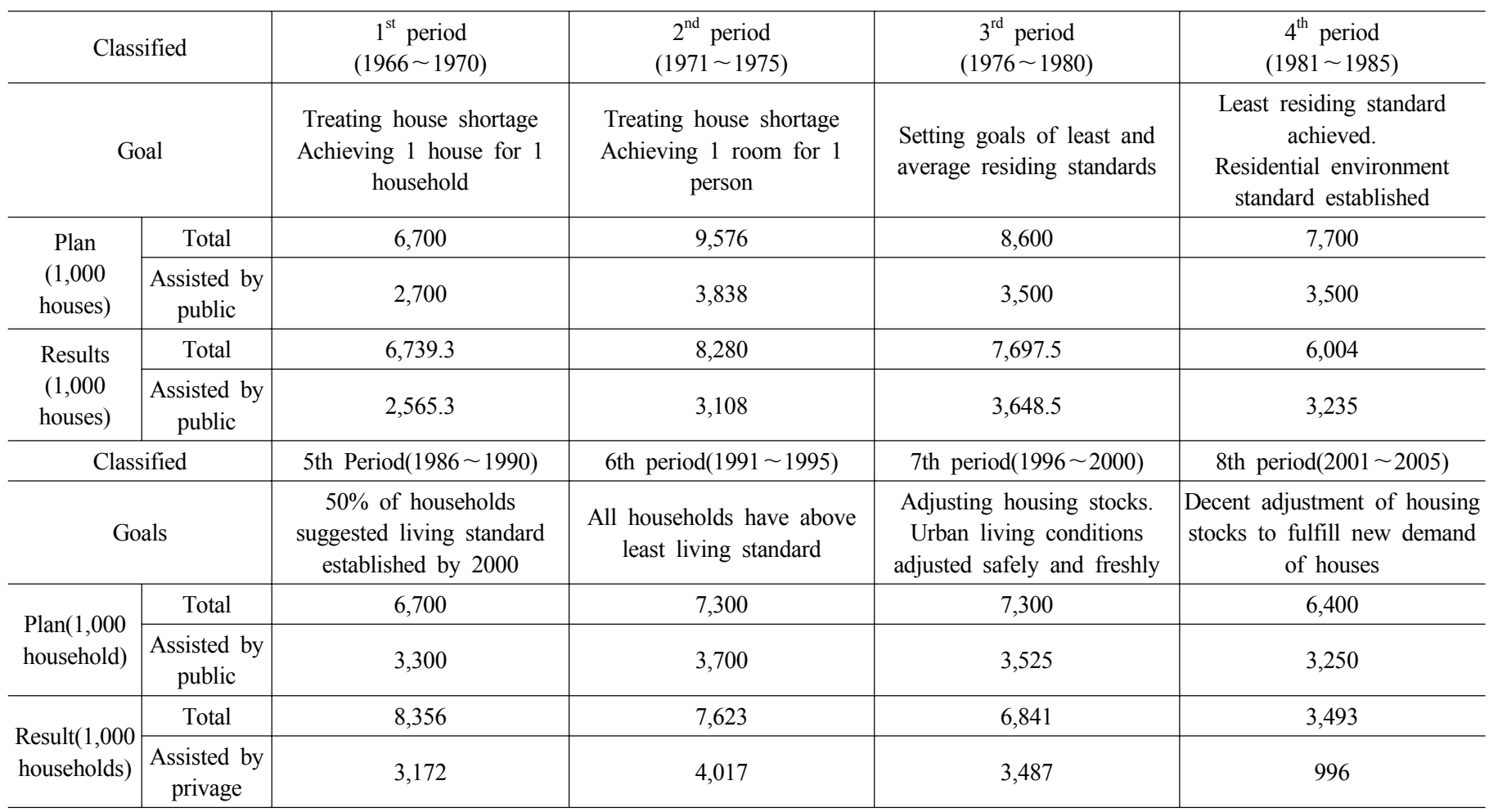

Source : modified and added from paper by Yoo Seong Yong (2006), p.119.

almost 1.8 times for 40 years: from 253 units per 1,000 people in 1968 to 452 in 2008 . The housing supply ratio also increased from $101.1 \%$ in 2008 to $115.2 \%$ in 2008 .

In general, housing quality can be defined as an appropriate living space in a house. The housing construction five-year program evaluated the space as an index. However, enhancing interior environment such as insulation and ventilation was more important than the quality of residential space. Housing policy in Japan has paid attention to supplying enough number of housing units compated to the number of households. But its focus has moved to the quality of residential space to improve the quality of residential environment.

National land development plans have been implemented which have been renewed every five year since the first National Land Plan was established in 1962. Although several development laws and system such as National Land Act have been implemented, effective measures and actions have not been executed in response to the problems of unbalanced regional development, spatial location and distribution of industries, and environmental impacts.

Due to rapid development and high growth during the 1960's, most regions have suffered from stagnancy in rural areas, the shortage of housing units, and unplanned development in urban 
Examining Japanese Planning System through the National Territory and Housing Policies: A Focus on Changing Characteristics and Implications

Table 5. A comparison of key indicators related to population and housing changes in both Korea and Japan

\begin{tabular}{|c|c|c|c|c|c|c|c|c|c|c|c|c|}
\hline \multirow[b]{2}{*}{ Years } & \multicolumn{6}{|c|}{ Korea } & \multicolumn{6}{|c|}{ Japan } \\
\hline & $\begin{array}{c}\text { Population } \\
(1,000)\end{array}$ & $\begin{array}{c}\text { Households } \\
(1,000)\end{array}$ & $\begin{array}{l}\text { Houses } \\
(1,000)\end{array}$ & $\begin{array}{c}\text { Members } \\
\text { per } \\
\text { household }\end{array}$ & \begin{tabular}{|c} 
Houses per \\
1,000 \\
people
\end{tabular} & \begin{tabular}{|c} 
Housing \\
supply ratio \\
$(\%)$
\end{tabular} & $\begin{array}{c}\text { Population } \\
\quad(1,000)\end{array}$ & $\begin{array}{c}\text { Households } \\
(1,000)\end{array}$ & $\begin{array}{l}\text { Houses } \\
(1,000)\end{array}$ & $\begin{array}{c}\text { Member } \\
\text { per } \\
\text { household }\end{array}$ & \begin{tabular}{|c|} 
Houses per \\
1,000 \\
people
\end{tabular} & \begin{tabular}{|c} 
Housing \\
supply ratio \\
$(\%)$
\end{tabular} \\
\hline 1970 & 31,435 & 5,576 & 4,360 & 5.64 & 139 & 78.2 & 103,720 & 28,093 & 25,591 & 3.69 & 253 & 101.1 \\
\hline 1975 & 34,679 & 6,648 & 4,734 & 5.22 & 137 & 74.4 & 111,940 & 32,141 & 31,059 & 3.48 & 285 & 104.7 \\
\hline 1980 & 37,407 & 7,969 & 5,319 & 4.69 & 142 & 71.2 & 117,060 & 36,015 & 35,451 & 3.25 & 308 & 108.0 \\
\hline 1985 & 40,420 & 9,571 & 6,104 & 4.22 & 151 & 69.8 & 121,049 & 38,133 & 38,607 & 3.17 & 323 & 109.7 \\
\hline 1990 & 43,390 & 11,355 & 7,160 & 3.82 & 165 & 72.4 & 123,611 & 41,036 & 42,007 & 3.01 & 342 & 111.1 \\
\hline 1995 & 44,554 & 12,958 & 9,205 & 3.44 & 207 & 86.0 & 125,570 & 44,108 & 45,879 & 2.85 & 367 & 111.5 \\
\hline 2000 & 45,985 & 14,391 & 10,959 & 3.20 & 238 & 96.2 & 126,926 & 47,063 & 50,246 & 2.70 & 397 & 113.3 \\
\hline 2005 & 47,041 & 15,887 & 12,495 & 2.96 & 266 & $105.9 / 98.3$ & 127,757 & 49,529 & 53,891 & 2.58 & 422 & 114.3 \\
\hline 2010 & 48,219 & 17,334 & 14,877 & 2.78 & 309 & 109.9/98.3 & 127,519 & 49,989 & 57,593 & 2.55 & 452 & 115.2 \\
\hline
\end{tabular}

Reference: * Houses of houses in Japan are statistics of 1968, 1973, 1978, 1983, 1988, 1993, 1998, 2003, 2008

** Statistics of Korea is from potential sum of 2010 population and house census, and housing supply ratio is statistics of 2008.

areas that resulted from massive influx of the people to three major cities (Tokyo ${ }^{12)}$, Osaka, and Nagoya). The central government has adopted growth pole strategy by establishing the National Development Plan to achieve balanced development among different regions.

In 1969, New National Land Plan ( $2^{\text {nd }}$ plan) was established to implement large development projects while focusion on improving living conditions in major cities. In 1977, the $3^{\text {rd }}$ National Land Plan was prepared to cope with excessive population density in the metro area of capital city. It aimed to vitalize local economy by moving national administrative organizations out of Tokyo, and building high-tech industrial facilities in local areas.

During the 1980's, many policies and strategies have been put into action not only for enhancing the role of Tokyo as a megalopolitan area, but also for balanced development throughout the country by relocating high-level functions of Tokyo to local cities. Between the 1990's and the 2000's, the National Grand Land Design of $21^{\text {st }}$ Century was established to realize multi-centric spatial structure throughout the nation(Kim and Seo, 2008).

\section{A comparison of socioeconomic conditions between Korea and Japan and its implications}

\subsection{Comparing social and economic backgrounds}

\subsubsection{Economic growth and changing land prices}

In terms of national economy, Japan has experienced explosive increases of land price for three times, and also suffered from long-term economic downturn for over ten years and a significant decline in land price. Accordingly, the urban regeneration

12) Population of Tokyo metro area was firstly recorded over 10 million people.
Table 6. A comparison of aging progress of Korea and Japan

\begin{tabular}{c|c|c|c}
\hline & Aging society & Aged society & Super aged society \\
\hline Japan & 1970 & 1994 (24 years) & 2006 (12years) \\
\hline Korea & 2000 & 2018 (18 years) & 2026 ( 8years) \\
\hline
\end{tabular}

policies for revitalizing the national economy have been planned and administered strategically since 2000 .

Korea also has undergone skyrocketing land price for two times which were happened in the late 1970's and in the late 1980 's, respectively. The fall of land prices was then followed after the International Monetary Fund financial crisis in 1998, even though the crisis has been stabilized with annual $5 \%$ growth rate in average since 2000 .

It can be stated that both of the early 1960's in Japan and the late 1970 's in Korea were similar in that two countries have suffered from rapid economic growth and soaring land prices. In addition, in the early 1970's in Japan and the early 1990's in Korea, they have been faced with economic crisis and presented a number of policies and measures to overcome the situation.

\subsubsection{Population change}

While total population of Japan was 127.76 million in 2005, Korea had 47.04 million residents in total, which indicated that Japan had 2.7 times as many as Korea in total population. About 3.1 times more households were living in Japan than in Korea as of 2005. Total population has decreased in Japan since 2006 while Korea is expected to be from 2019, which shows that the beginning of population reduction in Japan comes 13 years earlier than in Korea.

Looking into the ratio of 65 year or older people to total population in 2007, Japan showed $21.1 \%$ while Korea scored at $9.8 \%$ that was similar to the ratio of 1984 in Japan. Japan has already entered to the aging society in 1970, but Korea moved 
Table 7. A comparison of housing stock and supply in Korea and Japan

\begin{tabular}{|c|c|c|c|c|c|c|}
\hline & \multicolumn{3}{|c|}{ Korea } & \multicolumn{3}{|c|}{ Japan } \\
\hline & Houses $(1,000)$ & $\begin{array}{l}\text { New housing units } \\
\quad(1,000 \text { units })\end{array}$ & $\begin{array}{c}\text { New housing ratio } \\
(\%)\end{array}$ & $\begin{array}{l}\text { Houses } \\
(1,000)\end{array}$ & $\begin{array}{l}\text { New housing units } \\
\quad(1,000 \text { units })\end{array}$ & $\begin{array}{c}\text { New housing ratio } \\
(\%)\end{array}$ \\
\hline 1975 & 4,734 & 180 & 3.80 & 31,059 & 1,356 & 4.37 \\
\hline 1980 & 5,319 & 212 & 3.98 & 35,451 & 1,214 & 3.42 \\
\hline 1995 & 9,205 & 619 & 6.73 & 45,879 & 1,485 & 3.24 \\
\hline 2000 & 10,959 & 433 & 3.96 & 50,246 & 1,213 & 2.41 \\
\hline 2005 & 12,495 & 464 & 3.71 & 53,891 & 1,249 & 2.32 \\
\hline
\end{tabular}

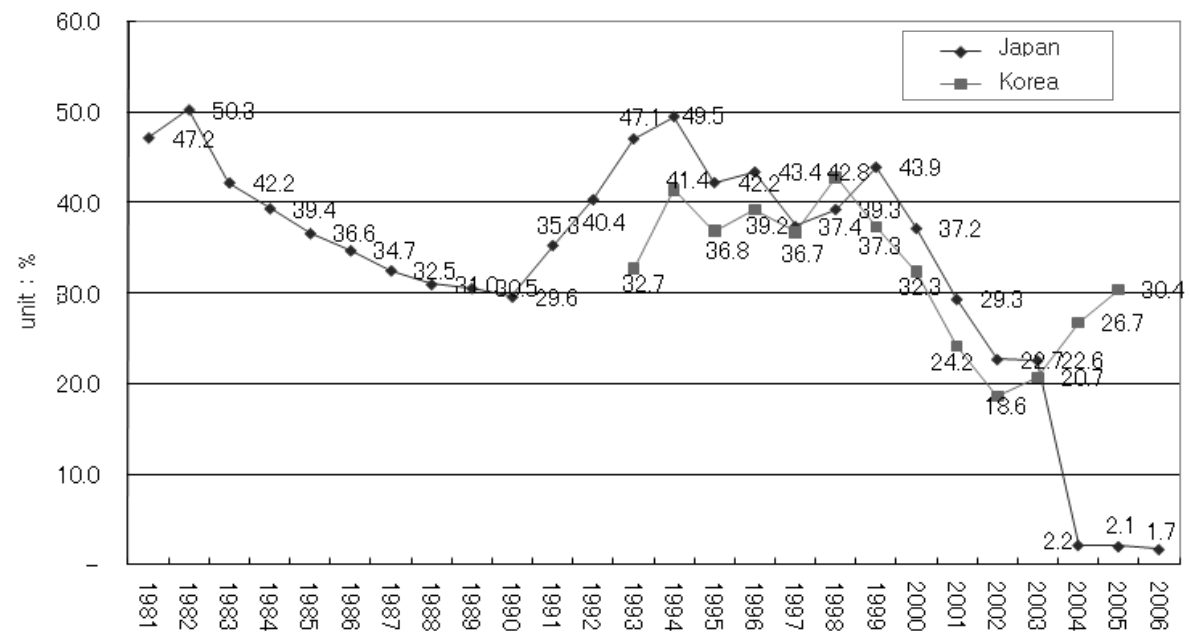

Fig. 6. The proportion of housing supply by the public sector

into it in 200013). The year of becoming the aging society in Japan was 30 years earlier than in Korea. In addition, that of becoming the aged society and the super aged society in Japan were 26 years and 20 years eariler than in Korea, implying that rapid progress has been made in Korea.

The number of members per household as of 2005 were 2.58 in Japan and 2.96 in Korea that was similar to the figure of the early 1990 's in Japan; however, the number of Korea in 2020 is expected to be 2.58, comparable to the number of Japan in 2005.

\subsubsection{Housing stock and housing supply ratio}

Total housing stock has increased in Japan by 2.3 times over last 40 years from 25.6 million units in 1968 to 57.6 million units in 2008. During the similar period, Korea has experienced the increase by 2.9 times: 4.36 houses in 1970 and 12.5 houses in 2010. The number of total housing stock of Japan in 1968 is about 5.09 times as many as that of Korea in 1970; however the gap

13) UN designates that the aging society is the society portion of 65 year or older population is more than $7 \%$, aged society is over $14 \%$, and in case of over $20 \%$, it is post aged society. between two countries has been diminished recently as Japan had about 4.3 times more houses than Korea.

The ratio of housing construction to total housing stock ${ }^{14)}$ in Japan was pacing down from $5.80 \%$ in 1970 to $3.42 \%$ in 1980 , which has been less than $3 \%$ since 2000 with the record of $2.41 \%$ in 2000. On the other hand, the ratio in Korea had greatly increased from $3.80 \%$ in 1975 to $10.48 \%$ in 1990 ; it has been, however, less than $4 \%$ since 2000 scoring at $3.96 \%$ in 2000 . It indicates that both Japan and Korea have been in similar conditions since 2000 .

Housing supply ratio as of 2008 was $115.2 \%$ in Japan and $105.9 \%$ in Korea. The ratio of Korea was similar to the level of Japan in the late 1970's. The number of houses per 1,000 people as of 2005 was 422 in Japan and 266 in Korea. The level of Korea in 2005 was comparable to that of Japan in the early 1970's. To summarize, the figures of Korea when compared to those of

14) Standards of construction projects are different in Korea and Japan. Korean basis is finishing of construction but Japan is starting of construction. But as it is difficult to get statistics specifically, cases of Japan are dealt as finishing projects. 
Japan indicate that Korea is still suffering from housing shortage problem as her levels are similar to those of Japan in 1970's.

In terms of housing supply ratio, it was in 1968 when Japan had firstly more than $100 \%$, which then has risen up to $105 \%$. But its speed became slower and reached above $110 \%$ at a stable degree of housing stock. On the other hand, the ratio of Korea had drop to $69.2 \%$ in 1987 which then has rapidly increased since 1988 until it became $100 \%$ in 2002 . The number of yearly supplied housing units had decreased since 1990. Housing supply reached to the peak of 950,000 of new housing units, and then the number has been evenly about 460,000 on an annual basis since 200415).

When it comes to the number of new housing units provided by by the public and private sectors, the proportion of the public housing units has rapidly decreased since 1995 in Japan: from $49.5 \%$ in 1994 to $2.2 \%$ in 2004 . It primarily diminished at the beginning of the Urban Renaissance Agenc (UR) which had been restructured from the Urban Development Corporation (UDC). That is a distinctive situation after 1990's as its housing supply ratio became over $100 \%$. In Korea, the balance of the public and private sectors had been 6 to 4 in 1990's; then the portion of the public sector has been smaller between 1999 and 2002, recording $18.6 \%$. After then, it has gradually grown to $30.4 \%$ in 2004 .

In terms of total housing supply by the public sector, both countries has showed similar numbers during the 1990's; however, it turned to be different after 2004. It is because Japan has executed administrative reform and employed knowhow from the private sector in order to get over economic downturn lasting for 10 years after the collapse of its bubble economy.

\subsection{A comparison between two countries and its implications}

In spite of apparently different policies related to national territory and housing development due to different conditions in two countries, basic framework of relevant policies is quite similar. The policies can be summarized in terms of national territory, housing, and urban planning and land use policies.

Above all, Korea has enacted the Act on Comprehensive Plan for National Territory Development in 2003 to deal with the limitations of the Forth National Territory Comprehensive Plan, and to accept the paradigms proposed by the plan and establish policies and specific plans for national territory (Heo, 2010). As it was necessary for Japan to transform the existing National Territory Comprehensive Development Act due to the changing trends, it was replaced by the National Spatial Planning Act. Both countries, therefore, have experienced some important changes in their fundamental directions and framework of the national territory planning.

The housing supply plan has been prepared in Korea every 10

15) Japan achieved $100 \%$ of housing supply ratio in national scale in 1968 (Korea achieved it in 2002). In 1973, the ratio of all prefectures were over $100 \%$, and $114 \%$ as of 2003 .
Table 8. A comparison of land and housing policies between Korea and Japan

\begin{tabular}{c|c|c}
\hline Cassification & Korea & Japan \\
\hline $\begin{array}{c}\text { National } \\
\text { territory }\end{array}$ & $\begin{array}{c}\text { Framework Act on the National } \\
\text { Land (comprehensive land plan } \\
\text { national, provincial, and } \\
\text { metropolitan) }\end{array}$ & $\begin{array}{c}\text { National Spatial Planning Act } \\
\text { (National Spatial Strategies : } \\
\text { national-local provincial } \\
\text { governments) }\end{array}$ \\
$\begin{array}{c}\text { Housing } \\
\text { policy }\end{array}$ & $\begin{array}{c}\text { Housing Act (Housing } \\
\text { pomprehensive Plan : national, } \\
\text { provincial and metropolitan) }\end{array}$ & $\begin{array}{c}\text { Basic Act for Housing } \\
\text { (Basic Plan for Housing : } \\
\text { national-metropolitan) }\end{array}$ \\
\hline $\begin{array}{c}\text { Urban } \\
\text { planning }\end{array}$ & $\begin{array}{c}\text { Utilization Act (metropolitan } \\
\text { planning, basic urban planning) }\end{array}$ & $\begin{array}{c}\text { City Panning Act } \\
\text { (City Planning master plan : } \\
\text { metropolitan, local) }\end{array}$ \\
\hline $\begin{array}{c}\text { Land use } \\
\text { policy }\end{array}$ & $\begin{array}{c}\text { National Land Planning and } \\
\text { planning, basic urban planning) }\end{array}$ & $\begin{array}{c}\text { National Land Use Planning Act } \\
\text { (national land use plan : } \\
\text { national, metropolitan, local) }\end{array}$ \\
\hline
\end{tabular}

years based on the comprehensive housing plan stipulated by Housing Act. In Japan, the Five-year Housing Construction Plan based on the Housing Construction Planning Act was changed to the basic plan for housing based on the Basic Act for Housing focusing more on residential and living quality. As explained previously, the housing plans of two countries are quite different in many points as with different number of housing supply. Housing policies in Japan is primarily paying attention to improving the quality of residential and living environment rather than the quantity of housing supply.

The deepest gap between two countries lies in urban planning and land use policies. In Korea, the National Land Planning and Utilization Act was enacted by combining both the National Territory Utilization and Management Act and Urban Planning Act so that both land use planning and urban planning were administered based on the integrated law. However, Japan still has two-tier systems: the National Territory Utilization and Planning Act and Urban Planning Act as done in Korea before 2003. In terms of urban planning and policy, urban regeneration has been an important issue when new planning paradigm has emerged. In this line, both countries have conducted many urban regeneration projects on a regular basis in that the Act on Special Measures Concerning Urban Renaissance was enacted in Japan in 2003, and the Special Act on the Promoting Urban Renewal was authorized in Korea in 2005.

To sum up, there are some gaps between two countries in terms of national territory, housing, and urban planning and land use policies; however, they are complementary rather than incompatible when it comes to changing policies in accordance of environmental changes in the future mainly due to similar framework of national territory and housing policies.

\section{Conclusions}

This article examined the changing characteristics of national territory and housing supply plans and policies along with the 
changes of social and economic conditions through the experiences in Japan. Major conclusions can be made as follows.

First, Japan has experienced fundamental changes in the mid 2000 's when the pivotal laws in relation to the national territory and housing policies were enacted. During the period, the National Territory Comprehensive Development Act and Housing Construction Planning Act were replaced by the National Spatial Planning Act and the Basic Act for Housing, respectively. These fundamental changes mean that the quality of residential and living conditions became more important than the quantity of housing stock. They also imply that new paradigm for spatial strategies of the national territory should be established in preparation to changing attributes such as population reduction and aged society.

Second, Japan adheres to free and competitive market system for housing supply except for public housing. Key housing policies has changed by decades in Japan: focusing on solving housing shortage problem between the 1960's and the 1970's, evolving to enhancing the residential and living quality between the 1970's and the 1990's, and paying attention to utilizing the market system for supplying housing stock.

Third, the number of annual housing construction amounted to 1.28 million in average between 1960 and 2002. But, it has diminished as the housing supply ratio reached to over $110 \%$. Although new housing supply has decreased, the amount of new residential units supplied was still excessive compared with its housing supply ratio. Historically, it became a cause of the collapse of the bubble economy in Japan. The experiences of housing development and supply in Japan should be considered in Korea when housing policies and plans are prepared.

Fourth, when it comes to comparing socioeconomic indicators between Korea and Japan, the population of Japan has been consistently decreasing after 2005, while that of Korea is estimated to be similar after 2018. Japan has become the aging society 30 years prior to Korea. It is also expected that Japan would be the aged society 26 years and the super aged society 20 years earlier than Korea, respectively. It implies we should prepare it because our society's aging pace is considerably fast.

In terms of housing stock, the number of new housing units in Japan (57.6 million in 2008) were 4.3 times as many as in Korea(14.9 million in 2010). However, it can be maintained that the number of housing stock in Japan is far more than in Korea because its population and households are about 2.7 and 3.1 times larger than those of Korea, respectively. In terms of the number of public housing supply, Korea is similar to Japan during the 1990's. After 2004, however, they have shown different characteristics. It is because administrative reform has been executed and knowledge and experiences from the private sector have been introduced to overcome economic recession for 10 years after the collapse of its bubble economy. In this regard, we anticipate that there will be significant changes in housing supply policies and mechanism in Korea.
As explained above, there are temporal gaps between Japan and Korea in the changes of national territory, housing, urban planning and land use policies mainly because of changing socioeconomic conditions. But their basic framework of national territory and housing policies are quite similar, which can provide policy implications for both countries to design their future directions and principles of relevant policies and plans. Through the comparative study of Japan's trends and distinctions caused by the changing attributes of national territory and housing policies along with the changes of social and economic situations, this research can be a starting point to investigate relevant policies and systems in more in-depth and systematic ways.

\section{References}

1. Cho, S.-Y. and Seo, S. T. (2009), "A Study on the Development Permit System for Urban Sprawl Control in Non-Urban Area : Case Study of Kanagawa and Manazuru in Japan", Journal of the Korean Urban Management Association, 22(1): 93 116.

2. Kim, K. Y. (2011), "The changes of housing policies and prospect after 2000", LHI Archives, 2(1): 45 52.

3. Kim, H.-A and Kim, H. W. (2004), "Comparative study of housing supply systems of Korea and other countries", Construction \& Economy Research Institute of Korea.

4. Kim, H.-A and Seo, J.-Y. (2008), "What is to be status of Act on House? Problems of housing promotion means", Urban Information Service, 310: 3 10.

5. Lee, S. S. et al. (2008), A Study on flow of land policy and related organizations of Japan, Land \& Urban Institute.

6. Lee, S. S., Wada. I and Lee Y. J. (2010), "A Study on the Coordination System of National and Local Land Use in Japan", Journal of Korea Planners Association, 45(3): 253 270.

7. Lee, Y. S. et al. (2010), Study on improving Act on Land Development Promotion and its Improvement, Land \& Housing Institute.

8. National Statistics Authority (2010), Result of provisional data of 2010 census.

9. Seo, S. T. (2011), "Achievements and prospects of current national land management system", LHI Archives, 2(1): 22 3.

10. Uemura, T., and M. Uto. (2010), "Proposal of Social Strategies in Japan until 2040: Coping with Problems of Housing, Land Use and Infrastructure Management Caused by Population Decline", NRI Paper 150, Nomura Research Institute.

11. Yoo, S.-Y. (2006), “Lessons from Japan's land development policy", 16(3): 116 133.

12. Homepage of National Statistics Authority (http://kostat.go.kr).

13. 川上征雄 (2008), 国十計画の変遷: 效率と衡不の計画理想 鹿島出版会.

14. 国土交通省·環境省(2008), 国土利用計画(全国計画).

15. 國土交通省, 住宅着工統計, 各年度.

16. 國土交通省, 住宅土地統計調査, 各年度.

17. 總務省 統計局, 國勢調査, 各年度.

18. 國土交通省(http://www.mlit.go.jp). 